\title{
FIRST SCANDINAVIAN SYMPOSIUM ON CARCINOGENESIS
}

$\mathrm{T}$ HE first Scandinavian symposium on "Carcinogenesis" was held at the Norsk Hydro's Institute for Cancer Research during November 16-18, 1961, being sponsored by the World Health Organization.

The symposium was intended as an informal meeting to create a closer contact between the Scandinavian research workers and to give them an opportunity to present their recent results and research projects, to co-ordinate the possible future work as well as to evaluate who is where doing what in Scandinavian carcinogenesis research. A total of 51 members participated: Denmark, 2; Finland, 3; Iceland, 1; Norway, 22; and Sweden, 23. There were 38 papers and 10 review lectures.

The symposium was divided into three parts. The first was presentation of the present work and research projects of the various laboratories (38 papers). A short summary of these papers-arranged in alphabetical order after cities-follows first.

Copenhagen was represented by Dr. J. V. Spärck (the Tuberculosis Immunization Research Centre, the State Serum Institute), who reported investigations on transplanted tumours in mice treated with X-rays and with cortisone. It was shown that irradiation chimæras possess particular features within various growth facets, for example, an inhibition of isologous tumour implants. Treatment of mice with high dosages of cortisone results in a marked inhibition of the progressive growth of tumours that is obtained after implantation of spontaneous mammary tumours, isologous to the recipients.

Helsinki was represented by Prof. K. Setälä and Drs. E. E. Niskanen and L. Stjernvall (Department of Pathology, University of Helsinki). These investigators reported results from investigations on the mechanism of artificial skin carcinogenesis in the mouse obtained by different techniques chemical, physicochemical, light-, polarization- and electronmicroscopical, biophysical. Particular attention was paid to the fact that it is possible to visualize dormant cellular features in mouse epidermis correlated with skin tumour evolution.

Lund was represented by Prof. C. G. Ahlström and Dr. N. Jonsson (Institute for Pathology), Prof. A. Levan and Drs. Audrey Fjelde, Eva Hansen-Melander and G. Östergren (Institute for Genetics), and Dr. B. Källén (Institute for Embryology)-all from the University of Lund. Prof. Ahlström and Dr. Jonsson presented in vivo and in vitro studies with two variants of Rous sarcoma virus as well as the characteristics of the resulting tumours. Mice, rats, hamsters, guinea pigs and rabbits of various age-groups served as experimental animals. There were significant differences between the oncological effects of the two variants or mutants of tho virological materials tested. Prof. Levan had analysed the chromosomes in sarcomas provoked by the Rous agent. Results were given indicating that the karyotypes had lost four chromosomes or gained one or three, respectively. It was concluded, for example, that there may be some similarity to the case of chronic myeloid leukæmia in man. Finally, the relations between carcinogenesis and chromosomal alterations were discussed. Dr. Fjelde had studied the different types of changes of cell populations of human cancer cell strains $H E P 1, H E p 2$ and $H S 1$ on the basis of tissue culture experiments. Dr. Hansen-Melander reported results of studies on the relation of chromosomes of the $M D$ mouse lymphosarcoma to carcinogenesis. Dr. Källén demonstrated tumour formation in the embryonic chicken brain, stimulated by surgically provoked disturbances in embryonic induction processes.

Oslo was represented by Drs. R. Eker, N. Arley, P. Fritzson and K. F. Nakken (Norsk Hydro's Institute for Cancer Research, the Norwegian Radium Hospital, Montebello), Prof. O. H. Lahelle and Dr. J. Jonsen (Virus Laboratories, the State Health Institute), Dr. J. Ulstrup (Ullevål Hospital), Prof. O. Torgersen and Dr. B. Óystese (Institute for Pathology, the State Hospital), and Prof. L. Kreyberg and and Drs. E. Evensen, O. H. Iversen and E. Mylius (Institute for General and Experimental Pathology, the State Hospital). Dr. Eker presented results from experiments on renal adenomas in rats. The results strongly support the view that the evolution of these tumours depends on a dominant gene. The effects on the tumorous growth of unilateral nephrectomy, castration, high dosages of 'Primoteston' and 'Estrafurin' were given. Dr. Arley gave a reviow of theoretical analyses of experimentally induced carcinogenesis, adding to the evidence that the evolution of both benign and malignant states can be started by a single gene-mutation, that is, a specific atomic substitution or rearrangement in a specific deoxyribonucleic acid (DNA) molecule. Dr. Fritzson had studied the effect of acetylaminofluorene (AAF) feeding on the uracil-degrading activity of rat liver. The results showed that addition of AAF to the diet caused a pronounced decrease in the activity of dihydrouracil dehydrogenase. The effect produced was dependent on the dosage of the carcinogen fed. It was concluded that the reduced activity of the uracil-degrading system should be a cancer-promoting factor. Dr. Nakken dealt with the role and mechanism of oxidation of aromatic amines to $o$-hydroxy-amines: $p$-amino-benzoacid reacted 3-6 times quicker with $\mathrm{OH}$-radicals than the radiation-sensitive pyridoxine and cysteamine derivatives. Prof. Lahelle and Dr. Jonsen presented new refinements concerning production and cultivation of the polyoma virus. It was possible to produce viruses in media that did not contain glutamine or serum. Dr. Ulstrup, too, presented new techniques for quantitative determination of polyoma virus. Prof. Torgersen presented certain experimental results on precursors of gastric cancer in mice. Iron-dextran was administered intragastrically to animals having artificially induced gas tric ulcers. This resulted in a marked penetration of the compound into the ulcerated area, vascular walls, etc., whereas normal gastric mucosa remained unaffected. Dr. Oystese gave results of studies on the pathogenesis of gastric cancer, carried out with fluorescence-antibody techniques. Dr. Evensen had 
studied the duration of cell division in the epidermis of hairless mice after exposure of the skin to methylcholanthrene and croton oil. It was shown that the earcinogen initially decroased both tho mitotic duration and the observed number of mitotic cells. After the first two days there was a marked increase in the number of dividing cells together with an increase of the mitotic duration. On the other hand, exposure of the skin to croton oil increased the number of mitotic cells without affecting the duration of coll division. Dr. Iversen dealt with the effects of different carcinogens on the mouse epidermis. It was shown that carcinogens initially lowered the DNA synthesis, more or less inhibited the mitotic activity and destroyed the mitochondria. The damage to the mitochondria was demonstrated by means of a tetrazolium reduction method, which revealed increased amount of formazan deposits in carcinogentreated epidermis. A blind test involving twonty substances gave support to the theory that the abovementioned changes in mitochondrial function is a specific effect of carcinogens. Dr. Mylius reported ultrastructural alterations of the epidermal mitoehondria in hairless mice provoked by a single local application of methylcholanthrene. Electron micrographs were shown which indicated that mitochondrial changes occurred within $24 \mathrm{hr}$. after the exposure to carcinogen. The alterations were more pronounced after eleven days. It was concluded that tho changes observed may interfero with the activity and functions of the mitochondria, altering the latter in a specific manner.

Reykjavik was ropresented by Prof. N. Dungal (Institute for Pathology, University of Iceland), who reported results from experiments concerning the correlation between the amount of polycyclic hydrocarbons in smoked food and development of various types of tumours in rats.

Stockholm was represented by Prof. L. Threnberg (Institute for Organic Chemistry), Drs. T. Gustafson and T. Hultin (the Wenner-Gren Institute) from the University of Stockholm, Prof. G. Kloin, Drs. Ingegerd Hellström, K. E. Hellström, Eva Klein, L. Révész, H. O. Sjögren and Britta Slettenmark (Institute for Tumour Biology, Karolinska Institute), Drs. B. Lagerlöf and B. Thorell (Institute for Pathology, Karolinska Sjukhuset), and Dr. A. Nilsson (Defence Research Institute). Prof. Ehrenberg dealt with the effect on rat lymphocytes of free radicals in irradiated foodstuffs and discussed the necessity of testing the possible carcinogenicity of irradiated foodstuffs in general. Drs. Gustafson and Hultin reported, respectively, on studies concerning the formation of enzymes induced by the substrate in animal cells growing in vitro, and of some effects of liver carcinogenesis in short-time experiments. Prof. Klein reviewed some recent work on the antigenicity of tumours induced by polyoma virus. Dr. Ingegerd Hellström dealt with in vitro experiments with tumours provoked by polyoma virus. Dr. K. E. Hollström roported results from studios on interstitial testicular tumours in mice induced by cestrogens. Dr. Eva Klein dealt with the antigenicity of induced tumours. Dr. Révész reportod on transplantation resistancy against induced tumours in isologous tumour-host systems. Dr. Sjögren had studied the interrelationship between transplantation characteristics of tumours provoked by polyoma virus. Dr. Britta Slettenmark reported on studies concerning the tumour-specific antigenicity of leukamia inducod by virus of the Gross type. Dr.
Lagerlöf gavo some results of leukæmia transformation in vitro. It was shown that the cells of normal bone marrow, by the prosence of leukæmia virus, are ablo to change into malignant cells: the shortest latency was fourteen days. Dr. Thorell had studied, by means of microspectrography, the chemistry of cells undergoing leukæmia transformation. Dr. Nilsson reported on results obtained during experiments with strontium-90 in mice. There developed various types of bone tumours in certain preferential sites of the skeleton.

Uppsala was represented by Drs. J. Hultén, L. Landerholm, J. Pontén and B. Stenkvist (Institute for Pathology, University of Uppsala). Dr. Hultén reported on studies of staining of normal and of malignant colon epithelium with fluorescein-protein conjugates. Dr. Landerholm had studied the various titres and morphology of the bone marrow during the development of virus-induced chicken erythroleukæmia. Dr. Pontén dealt with sex chromosomes as markers in transplanted chicken leukæmia cells. Dr. Stenkvist (together with Dr. Pontén) reported on relationship between virus-content, morphology and the phase of growth in progressing and in regressing Rous sarcoma.

The purpose of the second and third parts of the symposium was a general review and discussion of what is known and, especially, of what is not known to-day about the nature of experimental carcinogenesis, and to try, on the basis of theso discussions, to plan to co-ordinate future research in the Scandinavian countries in this field. The following ten reviews were then given, followed by comprehensive discussions: the present situation in tumour virology (Prof. C. G. Ahlström); the role in carcinogenesis of purified nucleic acids and similar extracts (Dr. Audrey Fjelde); pyrimidine metabolism during rat-liver regeneration and liver carcinogenesis (Dr. P. Fritzson); fluorescent antibodies applied in carcinogenesis research (Dr. E. Glück); theoretical models of growth and their importance in theories of carcinogenesis (Dr. O. H. Iversen); the implications of variation and selection for carcinogenesis and for the continued progression of tumours (Prof. G. Klein); considerations on endocrine carcinogenesis (Dr. B. Källén); the chemistry and biochemistry of aromatic amines in relation to carcinogenesis (Dr. K. F. Nakken); the role of the chromosomes in carcinogenesis (Prof. A. Levan); mechanism of experimental tumorigenesis in the mouse skin (Prof. K. Setälä).

In the discussion that followed the last paper, Dr. Kirstino Borum (Copenhagen) presented a short communication on the importance of the hair cycle in epidermal carcinogenesis in mice.

Since the symposium was an informal contact meeting, during which only the Scandinavian languages were used, no papers or proceedings will be published. However, the review lectures will be translated into Fnglish and, together with the abstracts of the thirty-eight papers cited above, filed with the World Health Organization's head office in Geneva and its regional office in Copenhagen, whore they may be studied by anyone interested.

It was decided to hold the second Scandinavian symposium on basic cancer rosearch in 1963 in Stockholm.

The participants wish to thank the World Health Organization and its officers for the grant which made this inspiring gathering possible.

Niels ArLey

KAI SeTÄI.̈̈ 